Vol. 5 (1996): 229-234.

\title{
Northern agriculture: constraints and responses to global climate change
}

Timo J.N. Mela

Agricultural Research Centre of Finland, Institute of Crop and Soil Science, FIN-31600 Jokioinen, Finland

\begin{abstract}
In the northern circumpolar zone, the area between the $600^{\circ} \mathrm{Cd}$ and $1200^{\circ} \mathrm{Cd}$ isopleths of effective temperature sum above $5^{\circ} \mathrm{C}$, the annual receipt of solar energy is limited by the low angle of radiation arriving at the earth's surface. This is the primary cause of the climatic constraints observed in the zone, such as low temperatures, a short growing season, frosts during the growing season, long and cold winters and thick snow cover. In Finland, the length of the growing season varies from 180 days in the south $\left(60^{\circ} \mathrm{N}\right)$ to 120 days in the north $\left(70^{\circ} \mathrm{N}\right)$. Consequently, the growing time for crops from sowing to ripening is also short, which limits their ability to produce high yields.

The most advanced forms of farming in the high-latitude zone are encountered towards the south in Northern Europe, central Siberia and the prairies of Canada, i.e. mainly in the phytogeographical hemiboreal zone where the effective temperature sum is higher than $1200^{\circ} \mathrm{Cd}$. Conditions for agriculture then deteriorate gradually further north with the cooling of the climate, and this is reflected as an increase in cattle rearing at the expense of grain cultivation. In northern Europe farming is practised as far north as to the Arctic Circle, at about $66^{\circ} \mathrm{N}$ latitude. In North America, fields extend to about $55^{\circ} \mathrm{N}$. In Asia, there are few fields north of $60^{\circ} \mathrm{N}$. Finland is the most northern agricultural country in the world, with all its field area, about 2.5 million hectares, located north of latitude $60^{\circ} \mathrm{N}$. Changes in the climate and atmospheric $\mathrm{CO}_{2}$ predicted for the future are likely to have a strong influence, either beneficial or disadvantageous, on the conditions for growth in northern areas where the annual mean temperature is $5^{\circ} \mathrm{C}$ or less.
\end{abstract}

Key words: Finland, circumpolar zone, crop production, growth conditions, growing season, solar radiation, temperature sum, winter damage

\section{Introduction}

The northern circumpolar zone, defined by climatic and vegetational criteria, delimits a highlatitude zone which comprises about one sixth of the world's land area. In these marginal areas adjacent to the polar region, man and nature approach the limits of their adaptability and the area is very thinly inhabited.

The zone is not uniform with regard to conditions for living organisms, as can be seen, for 
Mela, T.J.N.: Northern agriculture: constraints and responses to global climate change

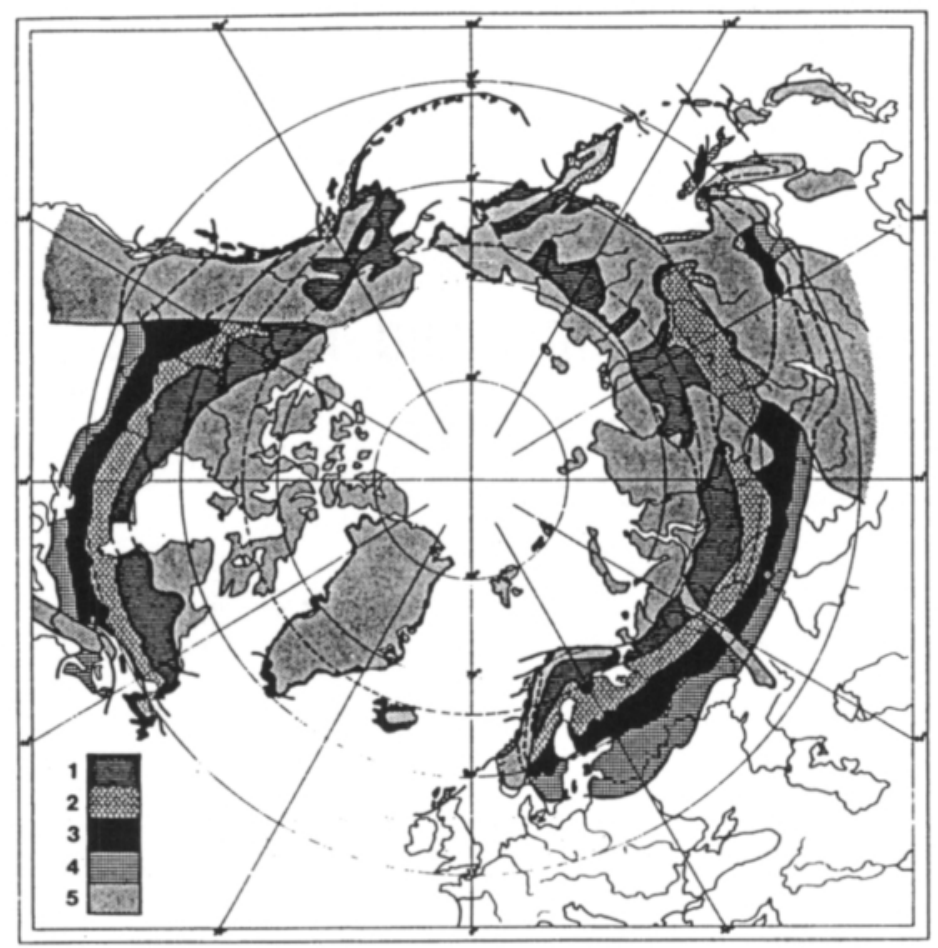

Fig. 1. The circumboreal zone and its transcontinental subzones. (1) Northern boreal, (2) middle boreal, (3) southern boreal, (4) hemiboreal and (5) arctic and complex, mountain areas (Hämet-Ahti 1981). instance, in the structure of agriculture. It is thus often divided into subzones on a biogeographical basis (Hämet-Ahti 1981). The circumboreal zone, characterized by dominance of coniferous forests, coincides to a great extent with the area between the $600{ }^{\circ} \mathrm{Cd}$ and $1200{ }^{\circ} \mathrm{Cd}$ isopleths of accumulated temperature above a base temperature of $5^{\circ} \mathrm{C}$ (effective temperature sum, ETS).

Considerable differences with respect to agriculture, forestry, reindeer herding, and other activities are to be found within this zone both between northern and southern areas and in an east-west direction. The most advanced forms of farming in the high-latitude zone (Fig. 1) are encountered towards the south, in northern Europe, central Siberia and the prairies of Canada, i.e. mainly in the phytogeographical hemiboreal zone where the effective temperature sum is higher than $1200^{\circ} \mathrm{Cd}$ (Varjo 1984). Conditions for agriculture then gradually deteriorate towards north with the cooling of the climate, and this is reflected as an increase in cattle rearing at the expense of grain cultivation until, at effective temperature sums of around $900{ }^{\circ} \mathrm{Cd}$, farming gradually gives way to forestry as the predominant form of economic activity. In northern Europe farming is practised as far north as the Arctic Circle, at about latitude $66^{\circ} \mathrm{N}$. In North America, fields extend to about $55^{\circ} \mathrm{N}$. In Asia, there are few fields north of $60^{\circ} \mathrm{N}$.

In Finland, agriculture is concentrated south of the $1000^{\circ} \mathrm{Cd}$ isopleth. The largest field areas, up to $50 \%$ of the total land area, are predominantly located south of the $1200^{\circ} \mathrm{Cd}$ isopleth. North of the $1000^{\circ} \mathrm{Cd}$ isopleth fields are rare; they cover less than $5 \%$ of the total land area. In the neighbouring countries agriculture is more southern than in Finland, in Sweden 90\% and in Norway $50 \%$ of cereals are grown south of $60^{\circ} \mathrm{N}$, as in Finland the total field area, about 2,5 million hectares, is located north of latitude $60^{\circ} \mathrm{N}$. 


\section{AGRICULTURAL AND FOOD SCIENCE IN FINLAND}

\section{Vol. 5 (1996): 229-234.}

\section{Climatic constraints}

In the circumpolar zone, the annual receipt of solar energy is limited by the low angle of radiation arriving at the earth's surface. This is the primary cause of the climatic constraints observed in this zone, such as low temperatures, a short growing season, frosts during the growing season, long and cold winters and thick snow cover. Only in the middle of the summer, when days are at their longest (between 18 and 24 hours) does the daily incoming radiation correspond to that of the middle and low latitudes. At this time, the gross $\mathrm{CO}_{2}$ assimilation rate of plants is correspondingly high.

The growing season in the circumpolar zone is short. In Finland, the length of the growing season (defined as the period with daily mean temperature exceeding $5^{\circ} \mathrm{C}$ ) varies from 180 days in the south $\left(60^{\circ} \mathrm{N}\right)$ to 120 days in the north $\left(70^{\circ} \mathrm{N}\right)$ (Mukula and Rantanen 1987). Consequently, the growing time for crops from sowing to ripening is also short, which limits their ability to produce high yields. Compared with countries in central Europe, the growing season in Finland is significantly shorter. For example, in Germany the season is one to three months longer than in southern Finland.

The long winters exert a considerable stress on winterannual and perennial plants. An ample storage of reserve carbohydrates is necessary to maintain vital functions through six to nine cold months. Low temperatures and winter diseases (Microdochium nivale Fr., Samu \& Hall, Typhula ishicariensis Imai, Myriosclerotinia borealis Bub. \& Vleug, Sclerotinia trifoliorum Erikss.) often damage and kill wintering plants. Winter diseases thrive in high temperatures under thick snow cover in the central and northern parts of Finland and they are the main reason for winter damage of perennial grasses and winter cereals. In the western coastal region, hard ice cover often suffocates wintering cereals and grasses.

Other climatic hazard factors include night frosts in the early summer or early autumn, which occur annually in some regions (Fig.2, Solantie

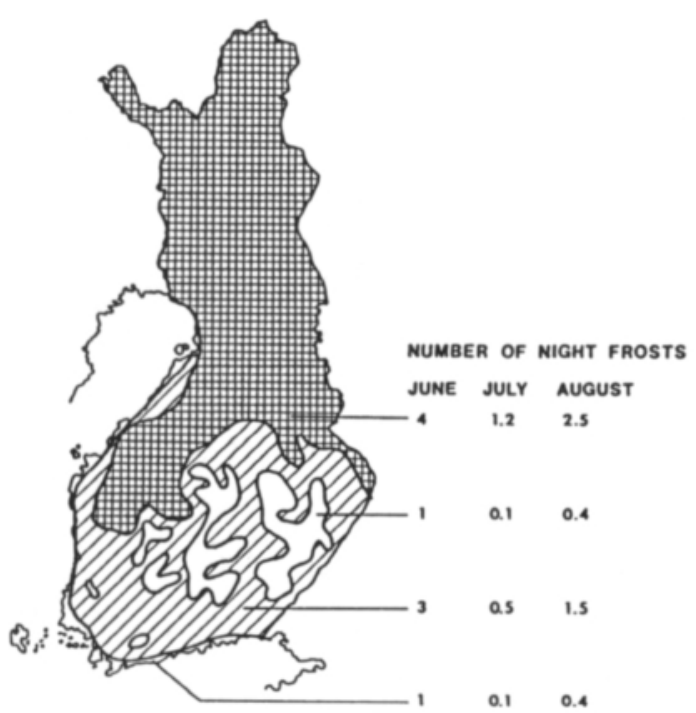

Fig. 2. Number of night frosts in June-July (Solantie 1980).

1980). The average number of night frosts varies from three to four in the agricultural area in June and from 1.5 to 2.5 in August. In a weather observatory $100 \mathrm{~km}$ north of the southern coast (Jokioinen 6049' $\mathrm{N}, 23^{\circ} 30^{\prime} \mathrm{E}$ ), every second year the last spring frost has occurred, on average, after 17 June and the last hard spring frost (under $-3^{\circ} \mathrm{C}$ ) after 1 June. Every fourth year there has been a hard spring frost on 8 June or later. The dates for the corresponding first frosts in autumn are 20 August, 9 September and $28 \mathrm{Au}$ gust, respectively. The average duration of the period without hard frosts is 100 to 114 days at inland locations away from lakes and one month longer at sites adjacent to lakes, which are safe areas for growing crops sensitive to frosts.

Another typical characteristic of the Finnish climate is a precipitation shortfall at the beginning of the summer. It is especially harmful for spring sown crops and grass grown for pasture and silage. Losses from drought are greatest in the coastal area on clay and silt soils. There is a high variability in climate from year to year, and cool, rainy summers occur a couple of times in a decade causing yield and quality losses. Varia- 


\section{AGRICULTURAL AND FOOD SCIENCE IN FINLAND}

Mela, T.J.N.: Northern agriculture: constraints and responses to global climate change

tions of yields are large (Mela and Suvanto 1987).

The number of crops which can be grown during the short growing season in the circumpolar zone is small, and they are mainly annual. In Finland, autumn-sown winter wheat and winter rye as well as spring-sown spring wheat for bread, spring turnip rape for oil and protein for feed, and sugar beet are grown in the southern parts of the country. The most common cereals in Finland, spring-sown barley and oats, are mainly grown for feed and are more widely distributed northwards. Commercial potato production, some for export, is practised in the north because under the northern conditions the number of aphids which transmit virus diseases is low. Perennial grasses and red clover are grown for forage as far north as the Arctic Circle and beyond.

Under northern conditions yields of all agricultural crops are low compared to those in middle latitudes. In central Europe, winter forms of wheat and barley as well as winter rape are predominantly grown and their yields are inherently higher than yields of spring cereals and spring turnip rape suitable for the Finnish conditions today. Growth of sugar beet is regularly cut short by autumn frosts in Finland. However, yields of field crops have doubled in the past 30 years in Finland due to increased fertilization, higher yielding varieties and improved crop husbandry. This trend is continuing and may even accelerate as a result of climate change.

\section{Changes in climate}

Predicted changes in climate as a result of the increasing content of so-called greenhouse gases, carbon dioxide $\left(\mathrm{CO}_{2}\right)$, methane $\left(\mathrm{CH}_{4}\right)$, nitrous oxide $\left(\mathrm{N}_{2} \mathrm{O}\right)$, tropospheric ozone $\left(\mathrm{O}_{3}\right)$ and halocarbons could have an important influence on the conditions for growth in northern areas. The most important greenhouse gas, $\mathrm{CO}_{2}$, which alone is thought to be responsible for about half of the anticipated global temperature increase up to the middle of the next century, also has a direct influence on plant growth. Recent scenarios predict a doubling of $\mathrm{CO}_{2}$ in the atmosphere over pre-industrial levels approximately between 2060 and 2070 for a "business-as-usual" scenario, with no changes to present policy (IPCC 1995).

An increase of mean global temperature in the range $1.5^{\circ} \mathrm{C}$ to $4.5^{\circ} \mathrm{C}$ is predicted as the equilibrium response to greenhouse gas forcing equivalent to a of $\mathrm{CO}_{2}$ (IPCC 1992). For the polar regions the increase is higher than the global means. Recent scenarios for the next century in Finland anticipate an increase in mean annual temperature of between $0.1^{\circ} \mathrm{C}$ and $0.6{ }^{\circ} \mathrm{C}$ per decade with a central estimate of $0.4^{\circ} \mathrm{C}$ per decade (Carter 1996). The central estimate of a $4^{\circ} \mathrm{C}$ warming by the end of the next century is of a similar magnitude as the warming between the end of the last Ice Ages 10000 years ago and the present day at northern latitudes.

Under this scenario, in a hundred years the growing season in southern Finland would be prolonged by 6-7 weeks, from 160-180 days to 200-230 days, which corresponds to the growing season in northern Germany today. The resultant shift of climatic zones in Finland would be about 500 to $650 \mathrm{~km}$ northwards (Carter et al. 1996).

\section{Effects on agriculture}

A change in mean temperature of the magnitude envisaged must have a significant effect on agriculture in the northern latitudes during the next few decades. The impact may be beneficial or disadvantageous. In Finland, increasing temperature is likely to enhance the growth of springsown cereals, especially in northern parts of the country. However, low temperature is not the only growth-limiting factor for some crops. For example, in southern Finland, lack of moisture during the early summer can be more harmful 


\section{AGRICULTURAL AND FOOD SCIENCE IN FINLAND}

Vol. 5 (1996): 229-234.

for the growth of spring barley (Kettunen et al. 1988). Moreover, a change in climate may benefit northern agriculture in several other ways than through temperature alone:

- An increase in carbon dioxide concentration in the atmosphere combined with a rise in temperature may increase the growth and yield of crops. However, increased water deficit in the soil caused by increased evapotranspiration under elevated temperature can disrupt the growth of crops.

- The period of snow cover is likely to become shorter and the overwintering risk to crops may diminish.

- Cultivation of high-yielding autumn sown crops can be expected to increase.

- A longer growing season may enable cultivation of higher yielding cultivars.

- The zones of suitability for crop species will expand northwards, including zones of crops not currently grown in Finland, which may move into southern Finland.

- The growing period for grass will be prolonged and yields will increase.

Cultivars which have a long period of growth benefit from a long growing season and develop slowly to increase the number of tillers, leaf area and root size, their apparatus for subsequent production of a high yield. When the growing season extends earlier in the spring and crops form green leaves earlier, they can take advantage of the long, often sunny days in May. This benefit, however, depends on a favourable frequency and timing of future spring frosts. Furthermore, the rapid shortening of days in the autumn may curtail the growth of crops in spite of continuing warm weather.

On the other hand, climate change may have disadvantages, including:

- Existing pests, diseases and weeds are likely to become more abundant.

- Exotic pests and diseases may appear.

- The need for plant protection will grow and, unless biological methods can be developed, the use of pesticides and fungicides, with related environmental problems, may increase.

- A reduction in soil frost, prolongation of the frost-free season and possible increases in precipitation may increase the risk of nutrient leaching.

- A warmer and longer growing season will accelerate the breakdown of soil organic matter, increasing problems of maintaining good soil structure.

On balance, however, the overall impact of a changing climate on crop yields in the circumboreal zone can be expected to be beneficial. The expansion of climatic zones northwards will lead to an increase in the agricultural potential of northern latitudes. Nevereless, the possibilities of the northern latitudes to respond to the increasing need of food in the world are limited because of the unsuitable soil and topographical conditions in many regions.

\section{References}

Carter, T. R. 1996. Developing scenarios of atmosphere, weather and climate for northern regions. Agricultural and Food Science in Finland 5: 235-249 (this issue).

- , Saarikko, R. A. \& Niemi, K. J. 1996. Assessing the risks and uncertainties of regional crop potential under a changing climate in Finland. Agricultural and Food Science in Finland 5: 329-350 (this issue).

Hämet-Ahti, L. 1981. The boreal zone and its biotic subdivision. Fennia 159: 69-75.
IPCC 1992. Climate change 1992. The supplementary Report to the IPCC scientific assessment. Houghton, J.T. et al. (eds.). Cambridge University Press. 200 p. - 1995. Climate change 1994. Radiative forcing of climate change and an evaluation of the IPCC 1992 emission scenarios. Houghton, J.T. et al. (eds.). Cambridge University Press. 339 p.

Kettunen, L., Mukula, J., Pohjonen, V., Rantanen, O. \& Varjo, U. 1988. The effects of climatic variations on 


\title{
AGRICULTURAL AND FOOD SCIENCE IN FINLAND
}

Mela, T.J.N.: Northern agriculture: constraints and responses to global climate change

agriculture in Finland. In: Parry, M. et al. (eds.). The impact of climatic variations on agriculture. Volume 1: Assessments in cool temperate and cold regions. Kluwer Academic Publishers, Dordrecht. p. 511-614.

Mela, T. \& Suvanto, T. 1987. Peltokasvien satoennuste vuoteen 2000 . Peltokasvien satojen ja niihin vaikuttavien tekijöiden kehitys vuoteen 2000 mennessä. (Prediction of the development of yields of field crops to the year 2000). Helsingin yliopiston kasvinviljelytieteen laitos. Julkaisuja N:o 14. 201 p.
Mukula, J. \& Rantanen, O. 1987. Climatic risks to the yield and quality of field crops in Finland. I. Basic facts about Finnish field crops production. Annales Agriculturae Fenniae 26: 1-18.

Solantie, R. 1980. Kesăn yölămpötilojen ja hallojen alueellisuudesta Suomessa. Maataloushallituksen Aikakauskirja 1980, 4: 18-24.

Varjo, U. 1984. The high-latitude zone: delimitation and characteristics. Nordia 18, 2: 93-104.

\section{SELOSTUS}

\section{Maatalous pohjoisilla äärialueilla: ilmastolliset rajoitukset ja ilmaston muutosten vaikutukset viljelyyn}

\author{
Timo J.N. Mela \\ Maatalouden tutkimuskeskus
}

Pohjoisella havumetsävyöhykkeellä auringon säteilyenergian vuotuinen määrä jää vähäiseksi säteilyn pienen saapumiskulman takia. Maataloutta harjoitetaan tällä alueella äärirajoillaan, sillä ilmaston kylmyys (matalat lämpötilat, lyhyt kasvukausi, hallat kasvukauden aikana, pitkät ja kylmät talvet sekä paksu lumipeite) rajoittavat viljelyä. Suomessa kasvukauden pituus vaihtelee etelän 180 päivästä pohjoisen 120 päivään. Tämän vuoksi viljelykasvien kasvuajan on oltava lyhyt, mikä rajoittaa niiden kykyä tuottaa suuria satoja.

Maatalous on edistyneintä alueen eteläosissa Pohjois-Euroopassa, Keski-Siperiassa ja Kanadan preerioilla ns. hemiboreaalisella kasvimaantieteellisellä alueella, missä kasvukauden tehoisan lämpötilan summa on korkeampi kuin $1200{ }^{\circ} \mathrm{C}$. Viljelyolosuhteet heikkenevät pohjoiseen päin ilmaston kylmetessä, ja viljan viljely muuttuu karjataloudeksi. PohjoisEuroopassa maata viljellään aina napapiirille $\left(66^{\circ} \mathrm{N}\right)$ saakka. Pohjois-Amerikassa pellot ulottuvat suunnilleen leveysasteelle $55^{\circ} \mathrm{N}$, Aasiassa muutamin paikoin leveysasteelle $60^{\circ} \mathrm{N}$. Suomi on maailman pohjoisin maa, jossa koko peltoala, 2,5 miljoonaa hehtaaria, sijaitsee leveysasteen $60^{\circ} \mathrm{N}$ pohjoispuolella.

Ilmaston ja ilmakehän hiilidioksidipitoisuuden ennustettu muutos vaikuttavat todennäköisesti voimakkaasti kasvuoloihin näillä pohjoisilla alueilla, missä vuotuinen keskilämpötila on $5{ }^{\circ} \mathrm{C}$ tai vähemmän. Vaikutukset ovat joko edullisia tai epäedullisia. 